\title{
Repositioning Implants Through Sandwich Osteotomy with the Interposition of Lyophilized Bovine Bone
}

\author{
Reposición de Implantes a Través de Osteotomía \\ Sandwich con Interposición de Hueso Bovino Liofilizado
}

\begin{abstract}
Claudio Ferreira Nóia*,***; Rafael Ortega-Lopes**; Bruno Costa Martins de Sá**;; Hugo Felipe do Vale ${ }^{* * *}$; Hélio Chagas de Oliveira-Júnior ${ }^{* * *}$ \& Catarina Soares Silveira ${ }^{* * *}$
\end{abstract}

NÓIA, C. F.; ORTEGA-LOPES, R.; DE SÁ, B. C. M.; DO VALE, H. F.; DE OLIVEIRA-JÚNIOR, H. C. \& SILVEIRA, C. S. Repositioning implants through sandwich osteotomy with the interposition of lyophilized bovine bone. Int. J. Med. Surg. Sci., 2(2):455-459, 2015.

SUMMARY: The satisfactory positioning of an implant during dental surgery is essential to the success of the treatment. However, accidents can occur during the period of osseointegration, leading to implant movements that hinder or may even prevent prosthetic rehabilitation. Implants can be repositioned through sandwich osteotomy, which has been labeled a versatile, viable and predictable technique in the literature. The aim of the present study was to report a case involving the esthetic displacement of an implant, caused by a sports accident, which was repositioned using sandwich osteotomy, with the interposition of lyophilized bovine bone between the osteotomized segments. In order to adequately perform this repositioning, the authors devised a guide to assist with the positioning process.

KEY WORDS: Osteotomy; Dental implants; Biomaterials.

\section{INTRODUCTION}

Nowadays, success in implantology is based on treatment that ensures long-term function, esthetics and stability (Kim et al., 2012; Nóia et al., 2012). The attainment of satisfactory results when using dental implants is completely dependent on several factors, such as adequate planning, the ideal three-dimensional position of the implant and the ability and experience of the surgeon (Bormann et al., 2011; Tavares et al., 2013; Laviv et al., 2014).

However, the adequate positioning of an implant during surgery does not guarantee that the implant will be in the same position at the time of prosthetic rehabilitation. During the osseointegration period, the patient may suffer some type of accident, such as a fall or a sports or traffic accident, which can displace the implant and hinder or even prevent prosthetic rehabilitation.

According to Raghoebar et al. (2005) and Tavares et al., once a dental implant has been diagnosed as malpositioned, from an esthetic point of view, the following treatment options are available: 1 - leave it in place, providing no support for a prosthetic rehabilitation; 2- remove and substitute the implant surgically or; $3-$ reposition the implant using sandwich osteotomy.

As well as repositioning implants, sandwich osteotomy can be used to treat moderate vertical defects of the alveolar ridge (between

* Dentistry Department, University of Araras (UNIARARAS/SP), Araras, Brazil.

** Dentistry Department, APCD Piracicaba, Brazil.

*** Dentistry Department, College Ciodonto, Rondônia, Brazil.

**** Dentistry Department, State University of Amazonas, Amazonas, Brazil. 
4 and $8 \mathrm{~mm}$ ). In the literature, the technique has been labeled versatile, viable and predictable, with few complications and a high percentage of success (Raghoebar et al.; Cunha et al., 2011; Nóia et al.; Bell, 2013; Felice et al., 2014; Xuan et al., 2014; Triaca et al., 2014; Stacchi et al., 2015).

Given the above, the aim of the present study was to report the case of a patient who had a sports accident that displaced a dental implant. This implant was repositioned using sandwich osteotomy with the interposition of lyophilized bovine bone.

\section{CASE REPORT}

A 28-year old male patient with leucoderma sought maxillofacial surgery after suffering a sports accident that moved the position of his dental implant. The clinical examination confirmed the absence of element 21 and the presence of the implant, which was malpositioned vertically and horizontally (Fig. 1).

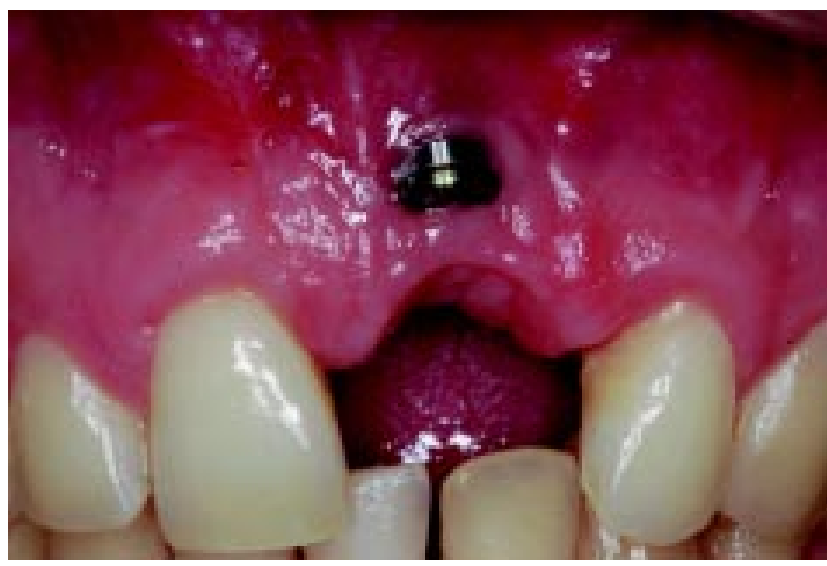

Fig. 1. Malpositioned implant. Note that the implant was displaced to an upper and vestibular position.

The treatment plan proposed to reposition the implant through sandwich osteotomy with the interposition of a lyophilized bovine bone graft block between the osteotomized segments. Due to the need to reposition the implant in both the occlusal and palatal directions, a guide was created from acrylic resin and a stock tooth was placed in the ideal position of the prosthetic crown

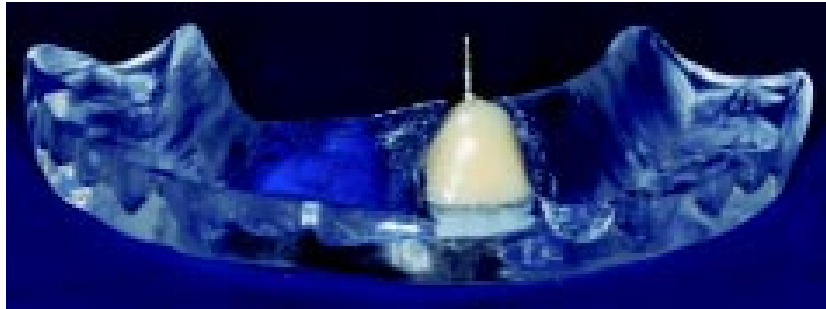

Fig. 2. Acrylic guide designed to help reposition the implant. Note that a stock tooth was put in place to simulate a prosthetic crown.

(Fig. 2). Thus, during the surgery, the bone graft block containing the implant should be moved until it connects with the positioning guide.

The surgery began with the anesthetic block, using articaine solution (4\%) and a vasoconstrictor 1:100.000 (Dfl, Rio de JaneiroBrazil), followed by a linear incision $3 \mathrm{~mm}$ above the mucogingival junction. Subsequently, mucoperiosteal displacement was carried out and the vertical and horizontal osteotomies were performed using sagittal saws. The finishing of the osteotomies, as well as the mobilization of the bone segment, were performed with chisels, taking care not to lacerate the palatal mucosa (Fig. 3).

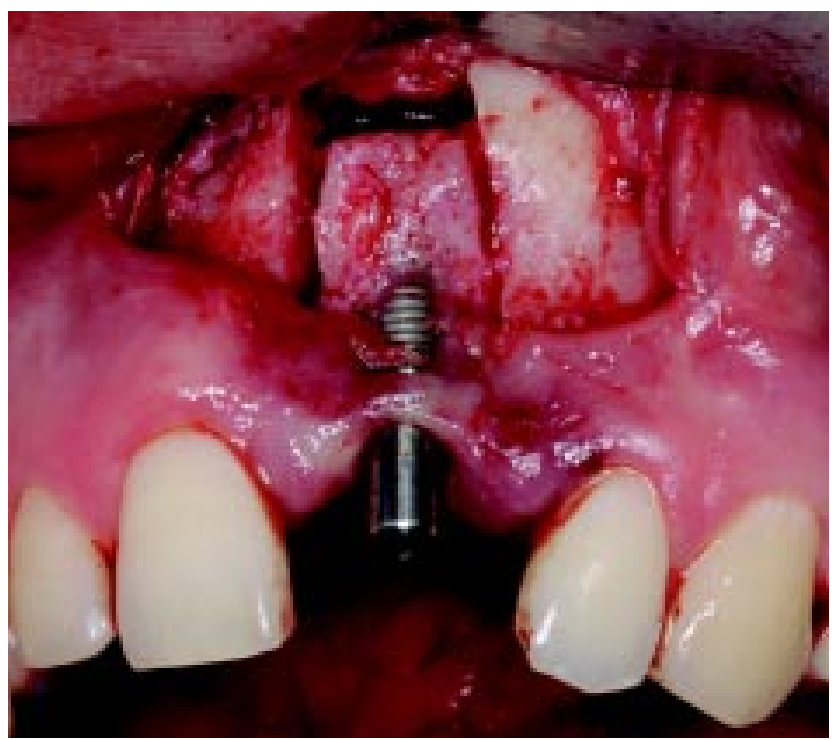

Fig. 3. Mobilized bone segment after the osteotomy had been performed. Special care must be taken to avoid lacerations on the soft tissue of the palatal region, since it will be the main source of nutrition in the post-operative period. 
Next, the acrylic resin guide was used to determine the ideal three-dimensional position of the implant (Fig. 4), while the bone segment was fixed with a $1.5 \times 14 \mathrm{~mm}$ screw (Engimplan, Rio Claro-Brazil). The space between the osteotomized segments was filled with lyophilized bovine bone (Lumina-Bone, Critéria, São Carlos-Brazil) and covered with absorbable collagen membrane (Lumina-Coat, Critéria, São Carlos-Brazil) (Fig. 5). The process was then finished with suture.

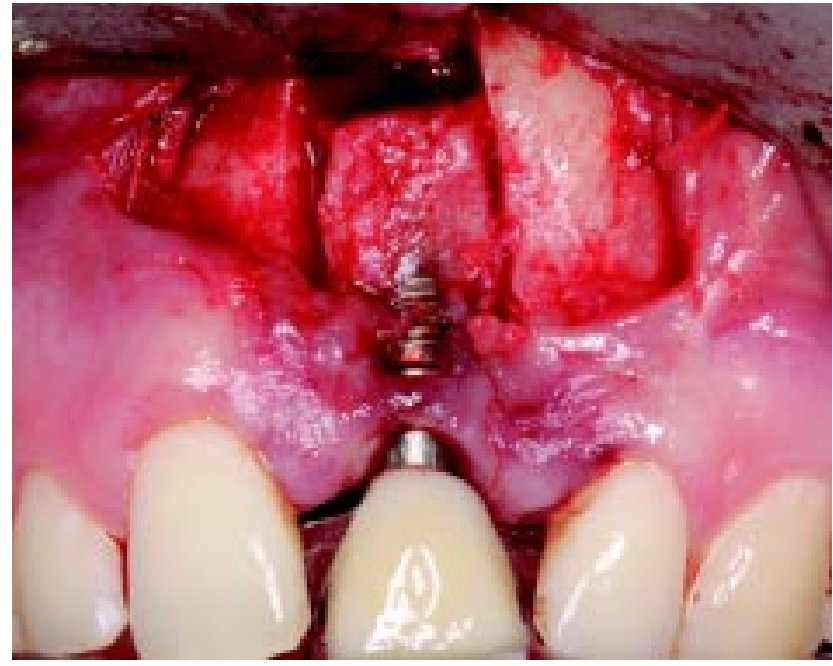

Fig. 4. Acrylic guide positioned on the neighboring teeth. Note that the guide orients the repositioning of the implant, determining how much it should be displaced in the occlusal and palatal directions.

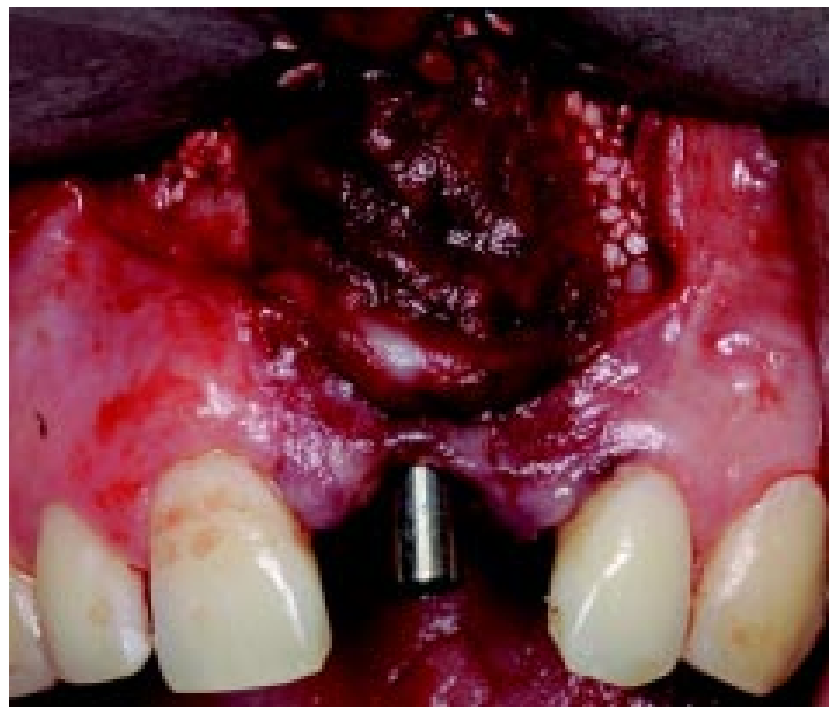

Fig. 5. Placement of the lyophilized bovine bone to fill the spaces between the osteotomized segments, as well as the resorbable collagen membrane isolating the graft from the soft tissue.
Four months after the repositioning surgery, the patient was reassessed and an excellent three-dimensional position had been achieved (Figs. 6 and 7). It was notable that it would be necessary to use a soft tissue graft to improve the gingival profile and the subsequent prosthetic rehabilitation. The case was then forwarded to the Department of Periodontics and Prosthodontics to finish the treatment.

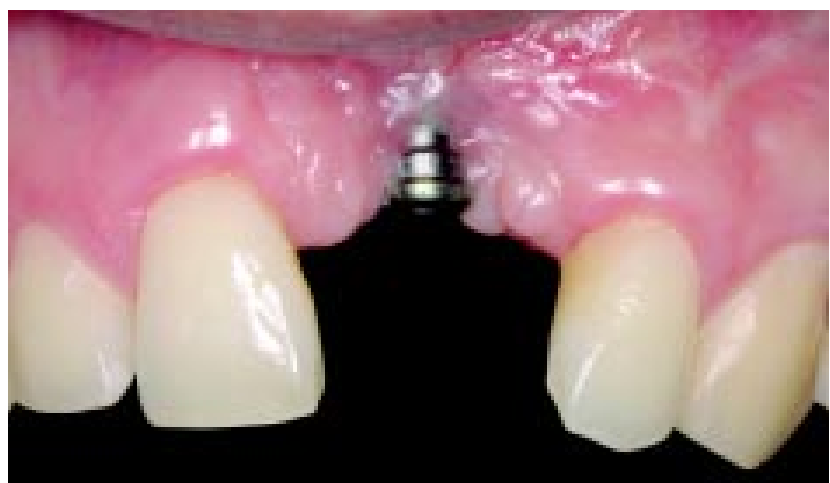

Fig. 6. Clinical aspect four months after performing the procedure. Note the excellent positioning obtained with the sandwich osteotomy technique.

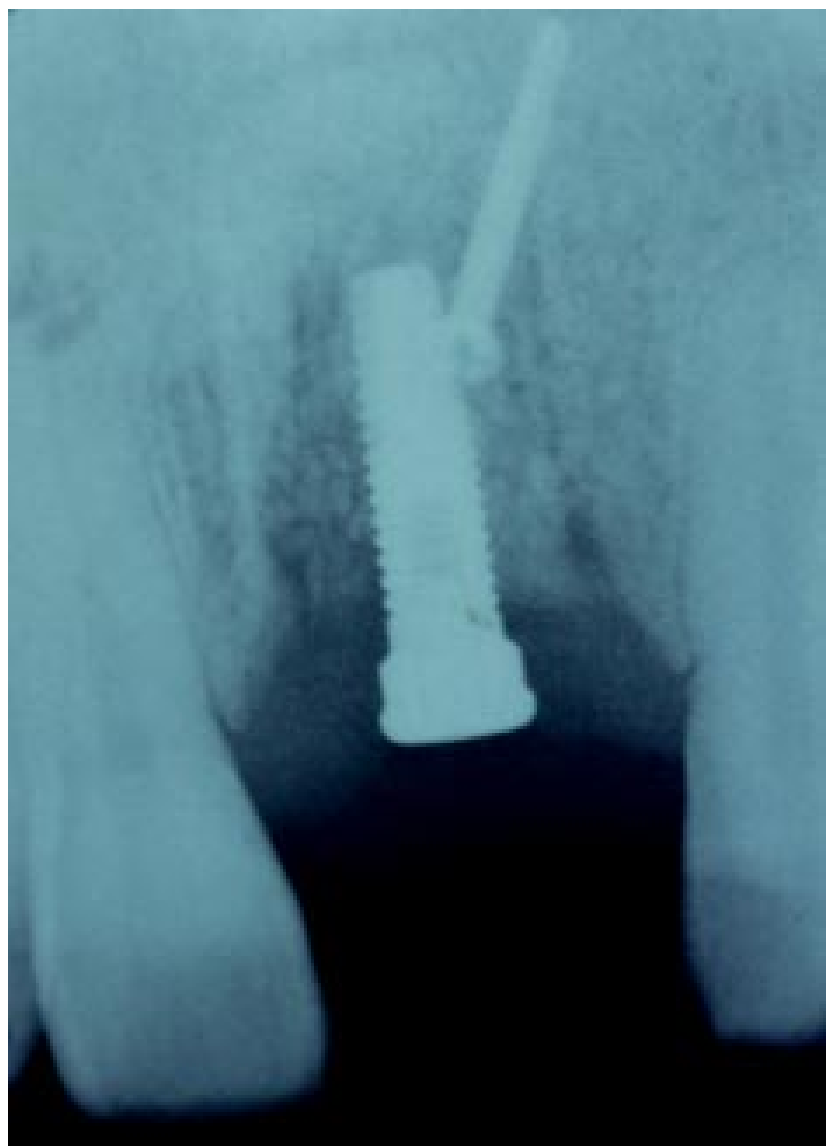

Fig. 7. Periapical radiograph showing the new position of the implant, as well as the fixation performed. 


\section{DISCUSSION}

Nowadays, patients that seek treatment with dental implants hope to restore their masticatory function, comfort, esthetics and phonetics, regardless of the existence of atrophy, disease or problems in the stomatognathic system (Kim et al.; Nóia et al.; Laviv et al.). In this context, the technique of sandwich osteotomy has been shown to be viable and predictable in the treatment of vertical defects of the alveolar ridge and in the repositioning of implants (Bormann et al.; Tavares et al.; Stacchi et $a /$.$) .$

Generally, dental implants that are malpositioned or at an excessive angle are caused by flaws in the diagnosis and planning processes, a loss of guidance during surgery or poor judgement in the case (Bormann et al.; Tavares et al.; Triaca et al.; Stacchi et al.). Reports of accidents causing the displacement of implants are rare in the literature, which makes this case all the more interesting and peculiar.

The vertical repositioning of implants has been carried out successfully without a positioning guide (Bormann et al.; Kim et al.; Stacchi et a/.). However, the present case involved both vertical (occlusal direction) and horizontal repositioning (palatal direction). Therefore, the authors designed an acrylic guide to assist in the ideal three-dimensional repositioning of the implant, thereby decreasing the possibility of errors. The authors did not find any similar reports in the literature.

Previously published studies using sandwich osteotomy routinely used autogenous bone as the interposition material between osteotomized segments (Raghoebar et al.; Cunha et al., 2011; Nóia et al.; Tavares et al.). However, these studies stated that the results of this technique are highly predictable due to the fact that the graft is in contact with four walls, which strongly favors nutrition and generates considerably less reabsorption.

Thus, the authors of the present study opted to use lyophilized bovine bone between the osteotomized segments. The clinical result four months after the procedure was favorable. These results will encourage us to use this type of material again in future procedures involving this technique.

NÓIA, C. F.; ORTEGA-LOPES, R.; DE SÁ, B. C. M.; DO VALE, H. F.; DE OLIVEIRA-JÚNIOR, H. C. \& SILVEIRA, C. S. Reposición de implantes a través de osteotomía sandwich con interposición de hueso bovino liofilizado. Int. J. Med. Surg. Sci., 2(2):455459, 2015.

RESUMEN: El posicionamiento satisfactorio de un implante durante la cirugía dental es esencial para el éxito del tratamiento. Sin embargo, accidentes pueden ocurrir durante el periodo de oseointegración, llevando a que el implante se ubique en posiciones de difícil rehabilitación protésica. Implantes pueden ser reposicionados a través de osteotomías "sandwich", para lo cual se ha probado su posibilidad y versatilidad siendo presentado como viable y predecible en la literatura actual. El objetivo de este trabajo fue reportar un caso que incluye el desplazamiento estético de un implante dental causado por un accidente deportivo donde se utilizó una técnica de osteotomía "sándwich" junto con hueso liofilizado bovino entre los segmentos osteotomizados. Para realizar esta reposición de forma adecuada, los autores plantean una guía para realizar el proceso.

PALABRAS CLAVE: Osteotomía; Implante dental; Biomaterial.

\section{REFERENCES}

Bell, R. E. Palatal Approach to the Anterior Maxillary Sandwich Osteotomy. J. Oral Maxillofac. Surg., 71(6):1005-9, 2013.

Bormann, K. H.; Suarez-Cunqueiro, M. M.; Von See, C.; Travassol, F.; Dissmann, J. P.; Ruecker, M.; Kokemueller, H. \& Gellrich, N. C. Forty Sandwich Osteotomies in Atrophic Mandibles: A Retrospective Study. J. Oral Maxillofac. Surg., 69(6): 1562-1570, 2011.

Cunha, H. A.; Filho, H. N. ; Batista, J. G. ; \& Matsumoto, M. A. Segmental osteotomy for the correction of a malpositioned single implant: An 8-year followup. Quintessence Int., 42(10):817-22, 2011. 
NóIA, C. F.; ORTEGA-LOPES, R.; DE SÁ, B. C. M.; DO VALE, H. F.; DE OLIVeIRA-JúnIOR, H. C. \& SILVEIRA, C. S. Repositioning implants through sandwich osteotomy with the interposition of lyophilized bovine bone. Int. J. Med. Surg. Sci., 2(2):455-459, 2015.

Felice, P.; Barausse, C.; Pistilli, R.; Spinato, S. \& Bernardello, F. Guided "sandwich" technique: a novel surgical approach for safe osteotomies in the treatment of vertical bone defects in the posterior atrophic mandible: a case report. Implant Dent., 23(6):738-44, 2014.

Kim, A.; Kar, K.; Nowzari, H.; Ahn, K. M. \& Cha, H. Subapical osteotomy to correct dental implant malpositioning and vertical ridge deficiency: A clinical report. J. Prosthet. Dent., 108(4):204-8, 2012.

Laviv, A.; Jensen, O. T.; Tarazi, E. \& Casap, N. Alveolar Sandwich Osteotomy in Resorbed Alveolar Ridge for Dental Implants: A 4-Year Prospective Study. J. Oral Maxillofac. Surg., 72(2):292-303, 2014.

Nóia, C. F.; Ortega-Lopes, R.; Mazzonetto, R. \& Chaves Netto, H. D. M. Segmental osteotomy with interpositional bone grafting in the posterior maxillary region. Int. J. Oral Maxillofac. Surg., 41(12): 1563-5, 2012.

Raghoebar, G. M.; Visser, A. \& Vissink, A. Correction of a Malpositioned Endosseous Implant by a Segmental Osteotomy: A Case Report. Int. J. Oral Maxillofac. Impl., 20(4):627-31, 2005.

Stacchi, C.; Chen, S. T.; Raghoebar, G. M.; Rosen, D.; Poggio, C. E.; Ronda, M.; Bacchini, M. \& Di Lenarda, R. Malpositioned Osseointegrated Implants Relocated with Segmental Osteotomies: A Retrospective Analysis of a Multicenter Case Series with a 1 - to 15-Year Follow-Up. Clin. Impl. Dent. Relat. Res., 15(6):836-45, 2015.

Tavares, R. N.; da Escossia, J. Jr.; Santos, S. E. \& Ferraro-Bezerra, M. Bone graft sandwich osteotomy to correct a malpositioned dental implant. Int. J. Oral Maxillofac. Surg., 42(7):901$3,2013$.

Triaca, A.; Brusco, D. ; Asperio, P. \& Guijarro-Martínez. $R$. New perspectives in the treatment of severe mandibular atrophy: "double sandwich" osteotomy. Br. J. Oral Maxillofac. Surg., 52(7):664-6, 2014.

Xuan, F.; Lee, C. U.; Son, J. S.; Fang, Y.; Jeong, S. M. \& Choi, B. H. Vertical Ridge Augmentation Using Xenogenous Bone Blocks: A Comparison Between the Flap and Tunneling Procedures. J. Oral Maxillofac. Surg., 72(9):1660-70, 2014.
Correspondence to:

Dr. Maximiliano Baruto

University of Araras (UNIARARAS)

Dentistry Department

Av. 500, Jardim Universitário, Araras

Zip-code: 13607-339

São Paulo

BRAZIL

Email: claudioferreira2004@yahoo.com.br claudionoia@uniararas.br

Received: 09-04-2015

Accepted: 18-05-2015 